\title{
Vicissitudes e Permanências: Produção, Saúde e Urbanização na Região de Campinas - SP
}

\section{Kleber Pinto Silva}

\section{Resumo}

Este estudo apresenta a estruturação do equipamento público de saúde na cidade e na região de Campinas, como um dos braços dos processos sociais, econômicos e políticos que transformam permanentemente a sociedade. Neste sentido, o desenvolvimento das cidades, assim como todos os elementos arquitetônicos e urbanísticos nele contido, apresenta-se como a feição material de tal estruturação. A questão do setor saúde e de seus espaços também comparece aqui como uma destas materialidades.

Num outro nível, complementar ao discutido, outra questão comparece neste trabalho, o rebatimento dos processos de estruturação da cidade na construção do desenho regional.

Com base nestes pressupostos, descreve-se parte da história urbana da cidade de Campinas e de sua região, além da constituição de seu sistema de saúde da segunda metade do século 19 aos anos 70 deste século.

Abstract

This paper studies the building of public health facilities in the city and in the region of Campinas as part of the social, economical and political process that transforms society permanently. This means that the development of these towns, like every one of their architectural and urbanistical elements, shows us the material face of those processes. The public health queries and their spaces also appear as one of these materialities.

In complementary way, another problem appears in this study: the repercussions the urban structurituration on the regional design process.

Based on these assumptions part of the city and the region of Campinas urban history, is related, describing the organization of its health system from 1850 until 1970.
Aluno de doutorado-FAUUSP 


\section{Origens da Centralidade Regional}

Campinas, como boa parte das vilas do período, teve origem, após a primeira metade do século 18, nas proximidades de antigo pouso de tropeiros. Durante longo período, até o final do século 18, esta região desempenhou o papel de divisor entre as áreas povoadas e não povoadas do centro-norte paulista.

A Freguesia de Campinas foi oficialmente elevada à categoria de vila na última década do século 18. Em sua região, somente as vilas de Jundiaí, Itú, Mogi-Guaçú e Piracicaba foram fundadas anteriormente.

Durante décadas a cidade possuiu parcas atividades econômicas, sendo que a fundamental era o suprimento de gêneros excedentes da produção agrícola de subsistência para as tropas que circulavam pelo caminho dos Guaiases. Além desta, ainda havia outra atividade, constituída pelo pequeno comércio de bens que supria o reduzido mercado urbano de então ${ }^{1}$ fornecendo também para a zona rural e os povoados vizinhos.

À medida que se intensificou a exploração das minas em Goiás ampliou-se a demanda por gêneros de consumo da época, graças ao fato de ser a mineração atividade única, dependendo totalmente do abas tecimento de gêneros produzidos fora das áreas de exploração. Tal fato fez com que uma série de vilas em São Paulo subsistisse à custa do fornecimento à zona mineira. Isto conferiu a estas vilas a característica, mais tarde ampliada, de centros de troca, em virtude da conformação da rede de caminhos.

Quando a produção de cana e de açúcar tomou o território da vila de Campinas, ao final do século 18 e especialmente no início do século 19, encontrou uma cidade dotada de uma estrutura urbana com funções e equipamentos minimamente delineados.

Cabe aqui uma observação acerca do porte da vila neste período. Quando de sua fundação (1774), o patrimônio de Campinas possuía pequena área, desmembrada da propriedade de Barreto Leme. Foram abertas apenas três ruas, as de Cima, do Meio e de Baixo, paralelas, com um pequeno número de quadras destinadas às edificações.

A cidade somente assumiu um porte significativo, em relação ao conjunto de cidades da então Província de São Paulo, à medida que a produção de açúcar aumenta, até torná-la a capital paulista do produto (final da década de 30 do século 19). Ampliou-se assim, sua função de centro regional de trocas, também possibilitada pela preexistência da rede de caminhos, agora transformados em rota de circulação de açúcar, o que já tornava Campinas, precocemente, uma "localidade central" Todavia, esta peculiaridade consolidar-se-ia em bases definitivas, somente com a implantação do sistema ferroviário na última metade do século 19.

Esta posição de centralidade rebate-se em suas feições. Se por um lado, por volta de 1840, a área urbanizada amplia-se, tomando quase todo o atual centro da cidade, por outro, as funções urbanas passam por um processo de ampliação,

(1) Tal restrição concretizava-se, em razāo da produção do período ser predominantemente de subsistência, realizada quase em sua totalidade dentro dos limites de cada uma das fazendas, 0 que as tornava auto-suficientes. No caso da reduzida populaçãourbana, as caracteristicas das moradias (grandes áreas disponiveis e cultivadas nos lotes) tambémsãodemonstrativas desta auto-suficiência. mantendo-a à frente em importância e porte, em relação às localidades da rede urbana paulista. A propósito, menciona-se a implantação das primeiras unidades fabris na cidade de Campinas, em finais de 1850, como a fábrica de chapéus Bierrenbach e a Fundição Faber.

Na produção agrícola campineira daqueles anos ainda predominava a cana e o açúcar. Porém, a produção de café expandia-se. Nos mesmos anos em que 
ocorreu o apogeu da produção açucareira, quando o cultivo da cana já havia se espalhado ao norte de Campinas (Mogi-Guaçú), a produção de café se consolidava.

O café representou para Campinas, assim como para o Estado de São Paulo, um momento em que todo um conjunto de novas atividades e funçōes passam a ser desenvolvidas. A cidade cresce rapidamente, disputando com São Paulo a primazia entre as cidades do Estado. Tanto que "(...) nesta entrada de década de 1870" a população campineira é de "33 mil indivíduos, enquanto a capital provincial possuía 26 mil" (Campinas, 1991, p. 19).

A medida que se ampliou a produção, começaram a surgir problemas para os produtores, tais como a escassez de mão-de-obra, as dificuldades no transporte da produção e a obtenção de crédito para financiamento da produção. Estes problemas foram paulatinamente solucionados com base na organização da classe de produtores rurais.

O problema da mão-de-obra foi solucionado com a imigração estrangeira e do transporte da produção com a implantação do sistema ferroviário. A venda da produção passou, aos poucos, a ser efetuada pelo comissariado sediado em Santos e mais tarde por nova categoria de intermediários com sede na cidade de São Paulo. Firmou-se também a categoria de banqueiros, com a abertura de grande número de bancos e casas de crédito.

Graças ao grande volume de capital disponível, oriundo dos lucros auferidos pela venda e beneficiamento do café, parte do excedente passou a ser investido na própria produção agrícola ou em setores a ela relacionados, como as companhias de imigração. Também em serviços de melhorias urbanas (infra-estrutura, embelezamento, etc.) e em outros ramos industriais, ligados ou não ao café, como maquinário para beneficiamento, implementos agrícolas, manufaturas diversas, etc.

Aanimação proveniente da nova forma de produção, agora nitidamente capitalista, refletiu-se nas cidades através de novos modos de vida. Especialmente por criar um mercado urbano de consumo de produtos industriais, propiciando o início de uma produção que aos poucos passou a industrial (século 20), como também pela formação de mercado urbano de trabalho. Em 1860 um viajante (Zaluar, 1975 , p. 133) passou por Campinas e registrou que "há três fábricas de licores, duas de cerveja, uma de velas de cera, uma de chapéus, três hotéis, (...). Há na cidade sessenta e quatro lojas de fazendas e ferragens, vinte armazéns de gêneros de fora e cento e dez tavernas (...) tudo paga direitos à municipalidade (...). O comércio é, pois, ativo e florescente (...) é aqui o entreposto de Goiás, Uberaba, Franca e outras povoaçōes do interior com a corte (...). Os campineiros formam suas associações literárias (...), aplicam as máquinas ao aperfeiçoamento da produção agrícola (...), não poupam esforços e fadigas para proporcionar à cidade todos os melhoramentos materiais de que carece (...): no calçamento das ruas e embelezamento das praças (...) na edificação de um mercado (...). O teatro de Campinas, melhor do que o da capital, faz honra ao bom gosto riqueza da população (...). A matriz nova (...) que é edificada (...), promete ser (...) o primeiro templo (...) da província toda"

A Campinas do século 19, especialmente nas três últimas décadas, passou por uma fase contínua de crescimento. Neste período surgiram na cidade e também em algumas das cidades da região inúmeras companhias de serviços públicos como iluminação pública a gás em 1875 e elétrica em 1886, bondes, telefones em 1884, etc. 
A prefeitura, às custas da arrecadação propiciada pelo café e apoiada financeiramente pelo Estado, investe pesadamente em obras de saneamento na última década do século, como meio de debelar as epidemias de febre amarela, iniciou a construção da rede pública de água e esgoto e embelezou a cidade abrindo e pavimentando ruas, praças e outros logradouros públicos.

Campinas sediava uma rica aristocracia rural, originária do antigo ciclo do açúcar, agora residindo na área urbana e não mais nas antigas fazendas, como outrora. Esta aristocracia fez trazer para a cidade um conjunto de atividades culturais, além de escolas, casas de saúde e outros estabelecimentos congêneres, ampliando grandemente o caráter polarizador de Campinas.

O primeiro estabelecimento destinado a cuidados com a saúde implantado em Campinas foi a Santa Casa de Misericórdia, inaugurada em 1876, que também mantinha o Asilo de Meninas (antigo Asilo de Órfãs), criado em 1878 para abrigar meninas órfãs pela mortandade das epidemias.

Ainda no século 19, foram criados, sempre distantes do aglomerado urbano, hospitais ou asilos para o isolamento de pobres portadores de moléstias contagiosas, todos eles desativados posteriormente. Em 1863, é criado pela Câmara Municipal o Asilo de Morféticos, transferido para novas instalações em 1878. Em 1895, estabeleceu-se a separação entre os sexos, construindo-se alas masculinas e femininas, este asilo foi demolido em 1933. Durante as epidemias de varíola, em 1874, é criado na cidade um hospital especializado que será fechado após o fim das epidemias.

Em 1879, inaugurou-se o hospital da Sociedade Portuguesa de Beneficência, criado para atender a colônia lusa residente na cidade, nos moldes de sociedades semelhantes espalhadas pelo país. Em semelhança à Beneficência Portuguesa, inaugurou-se em 1886 o hospital do Circolo Italiani Uniti, atual Casa de Saúde de Campinas. Observe-se que todas estas instituiçōes são privadas e, excetuandose a Santa Casa, não são destinadas às camadas pobres da população. Em 1864, é criado o único estabelecimento estatal (estadual) para assistência à saúde, o Centro de Saúde de Campinas.

Na década de 80, do século 19, foi criado e mantido pelo Estado o Hospital do Isolamento, abrigando as vítimas da febre amarela. Este estabelecimento foi fechado em 1898.

Vê-se, com base em tais fatos, que a cidade de Campinas, ao final do século contava com inúmeros estabelecimentos de atenção à saúde. A existência destes estabelecimentos a colocava, desde cedo, por um lado, como polarizadora de serviços também do setor saúde e de assistência social, mesmo que tais serviços fossem prestados, em sua maioria, por entidades privadas, por outro lado, demonstra o desenvolvimento porque passou a cidade naqueles anos.

Neste sentido, as populações das cidades da redondeza (de várias classes sociais), para ela acorriam em busca de seus serviços. À época Campinas já possuía um grande conjunto de estabelecimentos prestadores dos mais variados serviços, um centro comercial de peso, além de algumas manufaturas de tecidos, de máquinas e outras, graças a sua posição como "nó" do sistema de transportes regionais.

Com o advento das companhias ferroviárias (Paulista e Mogiana), Campinas passou por novo processo de animação. Grande quantidade de operários empregados na construção das ferrovias deslocou-se para a cidade. Este contingente mais tarde foi substituído pelos trabalhadores das linhas ferroviárias. 
As companhias construíram bairros inteiros destinados a abrigar esta nova população, como a vila industrial, situada do lado oposto ao centro, atrás da estação e dos trilhos. Inaugurada a estação, então distante do núcleo central, criou-se novo setor de expansão da área urbana. Ampliou-se a área do centro comercial e também residencial. Nas proximidades do terminal ferroviário instalaram-se também as primeiras indústrias, como a Cia. MAC Hardy e Lidgerwood, inúmeros armazéns para estocagem de diversos produtos destinados à exportação e uma série de oficinas para dar suporte à manutenção de equipamentos ferroviários.

Todas estas atividades eram realizadas por pessoal assalariado. Consolidou-se um grande mercado urbano de trabalho e de consumo.

Campinas firmou-se definitivamente como um dos nós do sistema paulista de transportes após a chegada da ferrovia, caráter ainda mais reforçado pela construção do ramal da antiga Cia. Ituana, ligando Campinas a Itú e, em menor escala, pela construção da Funilense ligando os atuais municípios de Cosmópolis e Paulínia a Campinas.

Com o período cafeeiro, Campinas passou a ter grande contingente populacional, vivendo e trabalhando na cidade. As atividades principais eram, ao final do século 19 e inícios do atual: o comércio, a prestação de serviços e um pequeno contingente de negócios industriais. Era também uma localidade bem servida, para os padrões da época, de um complexo sistema de transportes e comunicações. Dispunha, além disto, de um completo conjunto de equipamentos de infra-estrutura e de serviços urbanos, graças ao investimento de empresas privadas e também da municipalidade. Tal conjunto de elementos, além da existência de grande mercado de trabalho e de consumo, não se esquecendo também da proximidade com o grande mercado consumidor representado pela cidade de São Paulo, tornou Campinas um dos locais do Estado mais propícios ao investimento industrial. Tanto que, iniciada a industrialização brasileira, passou a cidade a sediar muitas atividades desta natureza.

É importante salientar que toda a animação por que passava Campinas no final do século foi interrompida por sucessivas epidemias de febre amarela (1888 e 1892). Neste momento a economia local passou por um período de desorganização, pois, era elevadíssima a mortalidade. A população local abruptamente passou dos cerca de 30.000 para 5.000 habitantes. Muitos dos moradores mudaram-se para cidades próximas ou para São Paulo. Iniciou-se então, um amplo e extenso trabalho sanitário, sob os auspícios da municipalidade e do governo estadual.

As intervenções tinham por objetivo interromper o processo de total desorganização econômica que ameaçava a província, assim como aos lucros dos produtores rurais do período. Este é o momento em que se ampliou consideravelmente a ingerência estatal na sociedade, através do setor saúde. Ainda, é claro, limitada e determinada pelos problemas que as diversas epidemias acarretavam à produção agrícola, bem como pelo fato dela atingir indiscriminadamente a todas as camadas da população.

Assim, o Estado nacional oligárquico de então, preocupado com a possibilidade de desestabilização econômica provocada pelas constantes epidemias, organizou um conjunto de procedimentos que definiriam, no futuro, as políticas públicas na área da saúde. Estas medidas constituiriam no embriâo do sistema nacional de saúde. 


\section{Estruturação do Serviço de Saúde Pública}

Durante séculos, no Brasil, a questão social da saúde foi relegada a segundo plano apesar das constantes epidemias que assolavam a população por toda parte. As atividades de saúde pública, sempre limitadas à questão do saneamento, prioritariamente na cidade do Rio de Janeiro e posteriormente estendidas a outras localidades portuárias, somente tornar-se-iam prioritárias quando ameaçavam desorganizar a produção econômica, em finais do século 19.

A organização da saúde pública na província de São Paulo era tão precária nos anos de 1831 a 1835, que muitas das cidades importantes da época, como Curitiba, Piracicaba, Franca, Itapetininga, Jundiaí e Pindamonhangaba, não contavam com médicos.

Os serviços de higiene e saúde pública somente implantar-se-iam, de modo mais organizado, a partir das reformas centralizadoras após 1850, por iniciativa da administração central do país. Assim, "a reforma dos serviços centrais de saúde pública, em 1886, estabeleceu que a província de São Paulo deveria ser sede de uma Inspectoria de Higiene, composta de um inspetor e de dois médicos (...). A capital ficou dividida em dois distritos, ficando cada um dos outros dois membros da Inspectoria, com o policiamento sanitário" (Mascarenhas, 1949, p. 36).

Anos mais tarde, ainda sob o espírito centralizador do estado nacional, os serviços de saúde pública passaram por nova reforma (1892) e desta vez os Estados da União assumiram a responsabilidade pelo controle de epidemias. Nesta época, a "teoria dos miasmas" foi substituída pela compreensão bacteriológica da doença, fato que determinou o modo como as epidemias foram abordadas. Extinguiu-se a Inspectoria de Higiene após a organização do Serviço Sanitário do Estado, subordinado ao secretário do interior.

As atribuições do Serviço Sanitário não estavam restritas às ações sobre as epidemias, cabendo-lhe também a organização e prestação de socorros de assistência pública aos necessitados.

Em continuação às atividades de combate às epidemias, surgiu em 1894 o primeiro código sanitário do Estado. O código regulamentava ruas, praças, habitaçōes em geral, hotéis e casas de pensão, fábricas e oficinas, escolas, teatros, alimentação pública, padarias, botequins e restaurantes, açougues, mercados, abastecimento de água, cocheiras e estábulos, casas de banho, barbeiros e cabeleireiros, lavanderias públicas, latrinas e mictórios públicos, hospitais e maternidades, esgotos, necrotérios, acidentes na rua, enterramentos, cemitérios, precauções imediatas contra moléstias epidêmicas e transmissíveis, vacinação e revacinação.

O Serviço Sanitário do Estado passou em 1896, por nova reorganização. Nesta reorganização o Estado foi dividido em três zonas: zona 1, a da capital, constituída por doze distritos sanitários, chefiados por inspetores sanitários; zona 2, Santos e Campinas, constituída por três distritos sanitários em cada cidade e zona 3, no território remanescente do Estado, dividido em doze distritos sanitários. Por esta nova estrutura o Estado, através dos inspetores, poderia intervir diretamente nos municípios, inclusive nos serviços municipais de saúde pública. Com base nesta reorganização, foram ampliadas as finalidades do Serviço Sanitário, bem como dos laboratórios de saúde existentes, como o Instituto Bacteriológico, entre outros. 
Todas as iniciativas em saúde, empreendidas pelo governo estadual, dos anos que se verificavam os primeiros surtos epidêmicos até o início da organização dos serviços de assistência à saúde foram de suma importância para Campinas, como ver-se-á em seguida.

Tais iniciativas permitiram à municipalidade campineira uma série de empreendimentos e de atividades para debelar as epidemias que se tornaram insumo ao desenvolvimento industrial da cidade a partir das primeiras décadas do século 20.

Em finais do século 19, o governo estadual instalou em Campinas o Centro da Comissão Sanitária do Estado. A municipalidade elaborou e implementou, sob a supervisão do engenheiro Saturnino de Brito um ambicioso plano de saneamento das áreas urbanas.

As precondições para a disseminação das epidemias de febre amarela vinham sendo dadas há algum tempo, em função das características do processo de urbanização do período ${ }^{2}$. Em função do surto de crescimento econômico experimentado por Campinas nos anos 80 do século 19, a população cresceu consideravelmente e proliferaram os cortiços. A cidade era cercada por áreas alagadiças e córregos, muitas vezes aterrados com lixo e detritos da própria cidade. Tais condições insalubres favoreceram a proliferação de agentes transmissores de doenças, dando origem às epidemias. "Face à emergência da situação decreta-se um estado de sítio sanitário. Muita gente sai às ruas para protestar. O estado de calamidade conferia enormes poderes aos agentes sanitários: podiam entulhar privadas, prender quem não entregasse os defuntos ao poder público, multar quem deixasse porcariada nos quintais, dar ordem de caiação de casas, de desinfecção de moradas. Prendiam quem impedisse a desinfecção de fossas. Interditavam e desinfectavam os mictórios públicos. Incineraram os ratos. Interditaram os hortigranjeiros vendidos pelas classes populares. Fiscalizavam o asseio das casas, nelas entrando a qualquer hora. Campinas recorre ao governo do Estado. Chegam créditos astronômicos. Vem a Companhia Campineira de Águas e Esgotos e instala destinaçōes de esgotos sanitários. Vem a lei estabelecer normas de ocupação do limite urbano: critérios de ventilação de casas, de espessura de paredes, de altura dos pavimentos. Proíbe-se a construção em áreas molhadas. Cria-se sistema de captação de águas pluviais. Planeja-se a destinação do lixo. Drenam-se os charcos da malha urbana. Vem a canalização subterrânea dos córregos. Em 1896, o número populacional prosseguia baixo. Em 1897 é oficialmente debelada a epidemia. Em 1898, um viajante desembarca na elegante estação ferroviária e vê ruas extremamente asseadas, muitas calçadas a paralelepípedos (...) e com passeios cimentados' A cidade se recuperara. Estava pronta para a ocupação. Em 1900 a área urbana já retornara aos quase 20 mil indivíduos. Estava saneada. Mas irreversivelmente perdera para a capital do Estado a primazia do desenvolvimento paulista. E muitas cidades, como São Carlos, Araraquara e Jaboticabal, haviam crescido às expensas da peste amarela campineira (Campinas, 1991, p. 23)."

\section{Campinas "Capital Regional": Urbanização, Industrialização e Expansão dos Serviços de Saúde}

Como vimos, antes das epidemias em Campinas, assim como no restante do Estado de São Paulo, e mesmo do Brasil, a atenção à saúde não era prioridade do Estado. Os cuidados para coma saúde eram dispensados predominantemente
(2) Condiçōes estas que se observarmos cuidadosamente, em nada diferem das que hoje sāo colocadas às nossas cidades. 
por particulares, muitas vezes autodidatas, ou através do conhecimento popular sobre ervas e outros. Os estabelecimentos por ventura existentes eram sempre privados, ligados a ordens religiosas ou irmandades laicas.

A cidade de Campinas adentrou o século 20 saneada. Todavia, a cidade vivia um período, iniciado com as epidemias, de relativo esvaziamento produtivo. Por um lado, a franja pioneira do café deslocava-se sempre mais a oeste, produzindo o surgimento de novos pólos regionais. Por outro lado, o locus de acumulação da economia transferiu-se para São Paulo. Além destes fatos, apontam-se outros. Não se renovavam mais as plantações de café com novas lavouras, como outrora. Tal fato associa-se à queda nos preços do produto a partir de 1897 , perdurando até 1911. Muitos dos fazendeiros e diversos empreendedores transferiram residência e estabelecimentos produtivos também para São Paulo, fugindo dos perigos da febre amarela e colaborando com a primazia urbana da capital.

Campinas e outras localidades do Estado pouco a pouco, ao longo das últimas décadas do século 19 , se industrializou. Também sob a economia cafeeira a cidade se modernizou, porém, apesar da semelhança entre os impulsos de expansão econômica, é na capital que os mesmos se deram com tamanha intensidade que sua população saltou dos cerca de 40.000 , em 1890, para os mais de 200.000 habitantes em 1900 . Neste momento a capital já se transformara em cidade industrial e a partir daí sobrepujará o Rio de Janeiro nos anos 20

O crescimento de Campinas acompanhava a evolução da base agrícola local e regional, o crescimento dos mercados urbano e rural de bens e a importância da cidade como entroncamento ferroviário. As áreas do território municipal com implantação industrial eram na cidade de Campinas, próximas à estação ferroviária e ao longo da ferrovia, a Usina Esther, no atual município de Cosmópolis e o bairro da Carioba, atual cidade de Americana.

Já em 1920, cerca de $50 \%$ da população total do município de Campinas era urbana. Pouco mais de $50 \%$ da população economicamente ativa ocupava-se no setor primário. A parcela restante, cerca de $40 \%$, dedicava-se a atividades tipicamente urbanas, tais como comércio, serviços e indústria. Em relação ao Estado como um todo, a população urbana economicamente ativa de Campinas detinha o terceiro posto, atrás apenas da capital e do litoral.

Durante toda a década de 20, acompanhando ainda a expansão cafeeira, a grande industrialização do Estado, a extensão da rede de energia elétrica e, ainda, a construção, por parte do Estado de nova rodovia ligando Campinas a Ribeirão Preto (1928), a região de Campinas passou por novo surto industrial com a implantação de novos e grandes estabelecimentos. Daí, até meados dos anos 50, quando ocorrerá novo grande impulso à industrialização, a indústria local continuou com sua marcha expansiva juntamente com a diversificação de sua produção.

Por todo o período, a face urbana da cidade de Campinas passou por algumas modificações importantes. Após o saneamento do aglomerado urbano, nas primeiras décadas do presente século, a municipalidade continuou a investir em melhorias urbanas, tais como a pavimentação de vias, aterros para corrigir depressões das vias e quadras, facilitando o escoamento das águas pluviais e melhoria no abastecimento de água de bairros situados em sítios elevados. Apesar do acréscimo populacional dos anos 10 e 20, a área da cidade não se expandiu, graças à reocupação do perímetro urbano do século 19 , esvaziado pelas epidemias. Até meados dos anos 20 a prefeitura ainda dispunha de alguns 
poucos lotes remanescentes do velho rossio, agora, quase todo ele ocupado. A partir de 1915 a prefeitura retomou os trabalhos de drenagem de áreas alagadiças preconizados pelos planos do eng ${ }^{2}$ Saturnino de Brito à época das febres.

Entre 1917 e 1918 foram realizadas grandes obras, como a marginal direita do canal de saneamento do córrego Anhumas, atual av. Orozimbo Maia. Em 1923 prolongou-se a av. Irmã Serafina, hoje av. Anchieta, canalizando-se o córrego Tanquinho.

A partir de 1925, com base no crescimento das atividades produtivas urbanas (terciário e secundário), alterou-se o padrão de urbanização até então estabelecido. Agora, entraram em cena a incorporação de novas áreas urbanas realizada pela iniciativa privada, cresce o valor do solo urbano, iniciou-se a especulação imobiliária, pois a prefeitura já não mais dispunha de lotes e a cidade tendeu a ultrapassar os limites do antigo rossio.

Esta ampliação das funções urbanas também foi sentida pelos setores de saúde e proteção social, em que foram criados muitos estabelecimentos: a Sociedade Amiga dos Pobres (Albergue Noturno, 1904); o Hospital de Socorros Mútuos (1904), estabelecimento este, privado; o Asilo dos Inválidos (1905), prestando serviços de assistência médica, entre outros e a Sociedade São Vicente de Paula (1907), que conta com a Casa da Criança, ambulatório médico e escola. Nos anos 10, inaugurou-se a Creche Bento Quirino (1914) e foi criada a Maternidade (1916), esta por um grupo de médicos, para assistir gestantes gratuitamente, dispondo também de ala para pagantes.

Nos anos 20, durante nova fase de expansão da cidade, inaugurou-se o Instituto Penido Burnier (1920), instituição privada para casos de oftalmologia; a seção de Assistência Médica da Prefeitura Municipal (1922); o Sanatório Dr. Cândido Ferreira (1924), destinado a doentes mentais; o Hospital Irmãos Penteado, dirigido pela irmandade de misericórdia, funcionando anexo à Santa Casa (1926); - Patronato São Francisco, para meninas (1927); o Instituto Brasileiro de Medicina e Cirurgia S.A. (1927); o Orfanato N. Sra. do Calvário (1928), para meninas órfãs; o Instituto D. Néri (antigo Abrigo de Menores) (1929).

Do lado da saúde pública, convém lembrar que em 1923 entrou em vigor a Lei Elói Chaves, primeira tentativa nacional para estabelecimento do sistema previdenciário e com ela são criadas as caixas previdenciárias, organizadas por empresas. Esta iniciativa representou claramente um segundo momento na história das instituições de saúde pública no Brasil, pois marcou, por um lado, o início da intervenção estatal na prestação de serviços em saúde e, por outro, na alteração do modelo de saúde, que passou da "polícia médica" dos tempos das epidemias urbanas, para a "promoção da saúde" do trabalhador urbano.

As caixas previdenciárias terão papel fundamental na prestação de serviços de saúde e também previdenciários, no futuro, como veremos a seguir.

No início dos anos 30 vários bairros foram criados - jardins Guanabara (projetado pela São Paulo Land \& Company Limited) e Chapadão, vilas Maria e Marieta, São Bernardo, Parque Industrial, Chácara Laranjeiras, e outros - ao redor do perímetro já constituído, através da subdivisāo de antigas chácaras e também de fazendas de café, agora não mais produtivas.

Como desdobramento da ampliação do setor terciário local, bem como do caráter regional de Campinas, foram criados no setor saúde, o Hospital Bierrenbach de Castro, para doentes mentais (1930); o Instituto Campineiro de Cegos Trabalhadores, prestando assistência médica e cultural aos internos (1933); o 
Hospital de Isolamento Dr. Francisco Arruda Rosso (1934), estadual; a Associação Protetora da Infância (atual Hospital Álvaro Ribeiro) (1936) e a Clínica de Otorrinolaringologia do Instituto Penido Burnier (1937).

A prestação de serviços em saúde começou a modificar-se durante estes mesmos anos, após a criação das caixas previdenciárias. Em virtude da pressão popular, com a ampliação da massa de trabalhadores urbanos, as caixas passaram a credenciar médicos para o atendimento dos empregados das empresas. A assistência à saúde dava-se, então, inicialmente através de consultas com os médicos credenciados e mais tarde as caixas manteriam serviços próprios, em suas sedes, ou em ambulatórios de fábricas. Este movimento foi crescente em Campinas, especialmente durante as décadas de 40 e 50, graças ao intenso processo de industrialização na cidade.

Ainda nos anos 30, começariam a ser criados os Institutos de Aposentadoria e Pensões (IAPs), organizados por setor produtivo (ferroviários, bancários, etc.) e não mais por empresas, com atribuições semelhantes as das antigas caixas.

Deste modo, a partir dos anos 30 , os serviços de saúde organizavam-se do seguinte modo: para atendimento à população de maior poder aquisitivo, haviam os hos pitais privados e médicos liberais; para os empregados e seus dependentes em setores já ligados às caixas previdenciárias, os hospitais e médicos conveniados; e finalmente, para a parcela da população pobre ou indigente, os poucos ambulatórios públicos e a Santa Casa de Misericórdia.

Ao lado das transformações urbanas, a municipalidade campineira, por seu turno, continuava preocupada como crescimento da cidade e com a falta de infraestrutura causada pelos loteamentos sem redes de água e esgoto, pela saturação das redes já implantadas, falta de pavimentação, etc. Em 1934 é aprovado o código de obras municipal, iniciando os longos trabalhos de melhoria das condiçōes urbanas, que se evidenciariam logo a seguir.

Seguindo os passos de São Paulo e tendo ainda viva a lembrança dos perigos da falta de saneamento, a municipalidade campineira contratou em 1934 o engenheiro-arquiteto Francisco Prestes Maia, a quem foi incumbida a elaboração de um plano urbanístico para a cidade, com o intuito de resolver seus problemas e prepará-la para o desenvolvimento futuro, já que a industrialização estava em curso e assumiria um papel fundamental.

Os estudos para o plano urbanístico estenderam-se por quatro anos, tendo sido aprovado o plano de melhoramentos urbanos de Campinas em 1938. Para suporte técnico à aplicação do plano, a prefeitura local efetuou uma reforma administrativa, organizando novos quadros técnicos (Seção de Arquitetura e Urbanismo e reformulação do Serviço de Cadastro e de Estatística) e completando outros já existentes (Diretoria de Obras e Viação e Diretoria de Águas e Esgoto).

Acerca do teor do referido plano, segundo a fonte consultada, "o plano de urbanismo, que se propunha implantar, na década de 30 , abrangeria um período de tempo situado entre 25 e 50 anos e previa que a cidade de Campinas, nesse período, teria sua população quadruplicada, isto é, atingiria cerca de 280 mil habitantes. Este crescimento (...) estaria intimamente relacionado ao desenvolvimento industrial (...) que se pretendia acolher e mesmo estimular com as propostas urbanísticas (...). O destino de uma cidade, segundo afirmava Prestes Maia, estava em grande parte ligado à sua função econômica e à sua importância regional (...). O urbano acelerava seu avanço sobre o rural, aproveitando a antiga trama de estradas, que da cidade irradiavam para o campo, ocupando 
seus interstícios mais próximos e assumindo uma configuração aneliforme que tendia a expandir-se em sucessivas etapas concêntricas (...), no interior da qual seria impressa, de forma cada vez mais nítida, a especialização do uso do solo (..). Prestes Maia captou este processo de transformação urbana e sobre ele propôs uma estrutura viária que consagrou as radiais e introduziu perimetrais que de espaço em espaço circundariam a cidade. Vias concêntricas foram propostas, contornando, sucessivamente, o centro histórico, o perímetro já construído, que o envolve, e a nova periferia em expansão, de modo a articular as radiais e conectar as diversas porçōes da área urbana" (Badaró, 1986, p. 82-84).

Além destas providências, Prestes Maia propôs a adaptação do centro da cidade aos novos tempos, através da remodelação da referida área, propondo a criação de espaços cívicos com edifícios públicos (paço municipal, fórum e repartições estaduais, correios, hotel, centro de comunidade, etc.), alargamento de ruas, preparando-as para o tráfego futuro de veículos, e a padronização de edificaçōes particulares.

Previu também áreas de expansão urbana, a provisão de bairros residenciais, dotados de parques, jardins, escola, comércio, zoneamento próprio e outros benefícios, bem como bairros industriais, além de zoneamento para todo o perímetro urbano.

Segundo o mesmo autor, a implantação do plano deu-se em duas fases, ao longo de várias administrações municipais, estabelecidas pelas condições econômicas do momento. A primeira, de 1934 a 1955, período de grande surto de crescimento, em que a industrialização se firmou de forma dominante na economia paulista. A segunda, de 1956 a 1961, quando se iniciou a implantação da indústria pesada no país, setor este que daria autonomia própria ao capitalismo indus trial brasileiro (Badaró, 1986, p. 155-156).

O plano, conforme o determinado por Prestes Maia, norteou toda a ação municipal de 1938, quando foi aprovado, até 1962, com complementações ou revisōes em 1940, 1951, 1954 e 1961

Reflexo da remodelação urbana, expressões do desenvolvimento econômico da região nos anos 40 e 50, ampliou-se ainda mais o "parque" de serviços de saúde local. Ao longo dos anos 40 surgiram o Hospital Psiquiátrico Santa Isabel, o Hospital Vera Cruz (antigo Hospital Stevenson) e o Instituto Pardo Meo-Muraro; também o Dispensário Dom Barreto (1941), para atender famílias pobres, dispondo de assistência médica e odontológica, lactário e posto de puericultura; a Casa dos Pobres (1941), o Posto de Puericultura anexo à Escola Técnica Industrial Bento Quirino (1944), o Ambulatório do IAPTEC (1947), o Posto de Puericultura do bairro Cambuí e a Casa de Saúde Dr. Modena (1948); seguemse o Posto de Puericultura junto ao Patronato São Francisco e a Clínica de Olhos Dr. Ozório Alves (1950). Nos primeiros anos da década de 50, Campinas contava com 198 médicos, distribuídos dentre as várias especialidades e 23 estabelecimentos de saúde, sendo 15 hospitais, 3 clínicas, 1 dispensário e 3 serviços oficiais de saúde pública. Estes estabelecimentos perfaziam um total de 1.686 leitos, sendo 1.472 gerais, 130 destinados a crianças e 84 a isolamento. Estes leitos destinavam-se a atender uma população total de 155.358 habitantes, dos quais 101.746 urbanos (Pereira, 1952, p. 563-564).

O setor saúde, especialmente em sua vertente pública, experimentaria a partir destes anos uma grande ampliação, evidentemente nos moldes iniciados na década de 20, com as caixas e institutos previdenciários. Neste sentido, L'ABBATE (1990, p. 191-193) observa: "até em torno da década de 50, a 
assistência médica à população de Campinas era feita pelos médicos em seus consultórios, nos hospitais, nos serviços médicos das fábricas e empresas, nas caixas de aposentadoria e pensões e nos ambulatórios dos institutos (...), os IAPs (...), a partir de meados da década de 30" Mas (...) "é sobretudo a partir dos anos 50 que os (...) IAPs começam a organizar a assistência médica-hospitalar em Campinas. Neste processo, os Institutos de Aposentadoria dos Ferroviários IAPFESP - e o dos Industriários - IAPI - foram os primeiros, seguindo-os os demais, o dos Comerciários - IAPC - os dos Funcionários dos Transportes Coletivos - IAPTEC" que em 1947 inauguraram um ambulatório médico na cidade, mencionado anteriormente, "e o dos Bancários - IAPB (...). O primeiro convênio foi o do IAPI com a Casa de Saúde, firmado em 1952 (...). Aos poucos, outros hospitais foram aderindo à política da previdência e estabelecendo convênios: a Beneficência Portuguesa com o IAPTEC, o Hospital Irmãos Penteado e Maternidade de Campinas prestando assistência ao parto aos segurados do IAPI, a Clínica Santo Antônio e a Clínica Pierro atendendo ao IAPFESP, o Penido Burnier dando assistência ao IAPI quanto a acidentes de trabalho e ainda mantendo convênio com o IAPFESP e o Hospital Vera Cruz com o IAPC"

Em suma, pode-se dizer que o desenvolvimento capitalista da região, como desdobramento do processo nacional, teve quatro fases. A primeira, até finais do século 19, com o apogeu da economia cafeeira. Neste primeiro momento, a cidade de Campinas consolidou-se como centro regional, com base no desenvolvimento de uma complexa rede de serviços e de infra-estrutura urbana e como mercado de mão-de-obra urbana. Ao mesmo tempo, a cidade de São Paulo transformou-se no centro propulsor da economia brasileira.

Na segunda fase, da última década do século 19 até a década de 30 , o ritmo de crescimento de Campinas, a despeito de contínuo e intenso, torna-se menor que o da cidade de São Paulo. Este é o período em que São Paulo consolidou-se definitivamente como o centro hegemônico do desenvolvimento industrial do país, hegemonia ou polarização esta exercida também, e com grande intensidade, sobre todos os antigos centros regionais do interior paulista. Apesar dessa hegemonia paulistana, Campinas se firmou como o maior e mais importante dos centros regionais paulistas, com base em seu parque industrial e em seu setor de comércio e serviços.

Dos anos 30 aos anos 50 o processo acima descrito tem continuidade, tanto para Campinas como para São Paulo. Campinas tornou-se, no referido período, um município de vida econômica predominantemente urbana e industrial. Colocandose e mantendo-se a partir deste momento entre as maiores e mais industrializadas cidades do Estado. Como exemplo, pode-se citar a implantação em Campinas e nos municípios vizinhos, sobretudo durante as décadas de 40 e 50 , de inúmeras indústrias multinacionais, como a IBM, Bendix, 3M, Eletrometal, entre outras. Do lado da iniciativa governamental, citam-se a inauguração da via Anhanguera em 1948 e a construção do Aeroporto de Viracopos, nos anos 50.

Nos anos seguintes os processos locais, reforçados e ampliados por iniciativas e incentivos governamentais de diversos tipos (municipais, estaduais e federais), tais como isenção de impostos, melhorias no sistema de transportes e de comunicação, fariam Campinas assumir o segundo posto (alcançado nos anos 70 e mantido a seguir) na atividade industrial do Estado.

Pode-se compreender, dos processos sócioeconômicos apresentados a configuração atual do município de Campinas, bem como de sua regiāo. Vejamos como. Toda a região de Campinas foi povoada por impulsos, como foi visto, 
gerados a partir do movimento de incorporação de terras para ampliação, inicialmente, da produção de cana e em seguida do café. Desde o primeiro dos ciclos (cana-de-açúcar), Campinas se firmou como a maior produtora da província, sendo de ocupação mais antiga, tem todo o seu território tomado por grandes e inúmeras fazendas.

Com base nos requisitos de cada uma das formas produtivas (e de capitalização das mesmas), criaram-se um conjunto de pequenos povoados, surgidos naturalmente ou por iniciativa institucional, muitos deles dentro das próprias fazendas, como Pedreira, Monte-Mór, Sumaré, no primeiro caso, ou delas desmembradas, como Cosmópolis, Jaguariúna e Nova Odessa, no segundo caso.

Destes núcleos, alguns eram pontos de parada obrigatória de tropas, como Vinhedo e Indaiatuba, assim como a própria Campinas; outros, eram simples povoações preexistentes, dinamizados pela implantação de estações ferroviárias, como Americana, Santa Bárbara D'Oeste, Valinhos e Paulínia.

Emsuma, a partir da existência prévia de povoações e da ampliação e adensamento produtivo das áreas rurais e, conseqüentemente populacional, em função dos diversos movimentos da economia, surgiu e desenvolveu-se o conjunto de núcleos urbanos mencionados. Tais fatos explicitam o intenso relacionamento exercido por Campinas e os municípios de sua região, muitos dos quais criados a partir de desmembramentos de seu território, já a partir da década de 50 do século 19.

Outro aspecto importante, também relacionado com o complexo produtivo, é a vinculação entre os movimentos econômicos seus adensamentos, os sistemas de transportes e os desmembramentos de municípios.

Iniciando-se por Campinas, a cidade, como vimos, foi criada nas últimas décadas do século 18, como parte do movimento de expansão dos domínios da colônia baseada na ocupação produtiva de novas terras, tendo início a produção de canade-açúcar. De meados do século 19 até a década de 50 do mesmo século a produção teve seu apogeu.

Da segunda metade do século $19 \mathrm{em}$ diante, evidenciando o adensamento produtivo e populacional propiciado pela produção cafeeira, teve início a criação de novos municípios na região, ao longo de antigas rotas de penetração. Indaiatuba, no caminho do "açúcar" que liga Campinas a Itú; Monte-Mór, também no caminho do açúcar, ligando-a a Capivari; Santa Bárbara, no de Piracicaba, do mesmo modo ligada ao caminho do açúcar; Pedreira, no de Amparo, ligado ao café.

Novos movimentos semelhantes foram registrados durante o século 20 . Americana, antigo distrito, desmembra-se de Campinas na década de 20, como decorrência de impulsos dinâmicos gerados pela extensão da ferrovia que partia de Campinas (por volta de 1875), da agricultura local (algodão) e da implantação industrial (tecelagem Carioba, também do final do século 19). Nos anos 40 , foram criados: Jaguariúna, desmembrado de Mogi-Mirim e fundada ao longo da mogiana; Cosmópolis, criado como núcleo de imigrantes na Funilense, ferrovia que o ligava a Campinas; e Vinhedo, desmembrado de Jundiaí, agora com sua sede transferida para as cercanias da estação da Cia. Paulista. Neste período, apesar de Campinas e algumas outras cidades da região como Jundiaí, Limeira e Piracicaba, viverem sob forte industrialização, as novas cidades surgidas tinham a economia ainda predominantemente agrícola. Nos anos 50 e 60, novos 
desmembramentos ocorrem. Sumaré e Valinhos, desmembrados de Campinas; Nova Odessa, desmembrado de Americana durante a década de 50; e Paulínia, ainda de Campinas, em 1964. Mais recentemente, em 1991 desmembram-se, Hortolândia de Sumaré; e Holambra de Jaguariúna e Cosmópolis.

Retomando a discussão do desenvolvimento econômico na região de Campinas, observa-se que seu crescimento industrial poderia ser subdividido em dois períodos. Até os anos 30, a maior parte dos impulsos industrializantes são absorvidos pela cidade de Campinas, quando ela se firma como a localidade central da região e de grande área do interior do Estado. A partir dos anos 40, e sobretudo 50, tais estímulos continuariam a ser absorvidos por Campinas; entretanto, já despontarão novos centros industriais na região: Valinhos, Vinhedo, Sumaré, Nova Odessa, Americana, Santa Bárbara D'Oeste e Indaiatuba, agora ao longo do eixo estabelecido pela via Anhanguera ${ }^{3}$, em virtude do tipo de estabelecimento, ou seja, a grande indústria, que tem necessidade de implantação em áreas maiores.

Nos anos 60 e 70 incorporar-se-iam ao rol de localidades industrializadas, as demais cidades, Paulínia, Cosmópolis, Jaguariúna e Monte-Mór.

Lembre-se que a cada novo estímulo industrializante, as localidades de implantação industrial mais antiga passavam por novo adensamento e ampliação de seus parques. Tais estímulos, entretanto, não significam apenas crescimento no número de estabelecimentos industriais principais, mas de outros que thes são complementares. Significam também que a cidade amplia também os demais setores (comércio e serviços), fazendo frente ao conseqüente aporte populacional. Ampliar-se-ão, dentre outras, também a área urbanizada, bem como as demandas sociais e econômicas (transportes e comunicações, infraestrutura e serviços diversos).

Ao longo de todo este processo, a regiāo passou por sucessivas ampliaçōes em sua populaçāo, assim como transformaram-se as próprias localidade.

\section{Urbanização Acelerada, Pauperização e Saúde: anos 70}

Quando se iniciou a primeira fase de industrialização pesada (décadas de 50 e 60), Campinas e algumas cidades da região já se encontravam preparadas para receber as novas indústrias, devido às suas excepcionais precondições de infraestrutura para instalação industrial. Alguns ramos foram especialmente atraídos, como o mecânico, o metalúrgico e o químico. Também deste período datam grandes investimentos federais, constantes do plano de metas do governo federal, em infra-estrutura. O governo estadual também investiu consideravelmente no período, especialmente na melhoria da malha rodoviária, como foi o caso da duplicação da via Anhanguera.

Apesar de todo o desenvolvimento industrial, a região de Campinas mantinha-se na liderança da produçāo agrícola de vários produtos, graças ao sis tema fundiário regional - de pequenas e médias propriedades - e a seu alto grau de capitalização. Este processo teve início já na década de 30, após a crise do café, com a policultura sempre presente na região. Por estas caracterís ticas, o setor agrícola regional esteve ligado, sobretudo após a década de 30, a economia urbana, complementando-a, ou ainda, produzindo gêneros para mercados externos. Assim, a agricultura como um todo também colaborou para fortalecer os mercados urbanos regionais. Todavia, o período de crescimento feérico veio a 
acontecer na década de 60 , com seu apogeu na década seguinte e daí mantendose em ritmo menor nas décadas seguintes. Após 1964, notadamente 1967. o Brasil viu seu processo de industrialização se consolidar, com base na implantação dos segmentos pesados, isto é, de base da produção industrial apoiado em um conjunto de investimentos diretos ou indiretos (incentivos).

Neste momento (anos 60) a maior beneficiada foi a região metropolitana de São Paulo, mas mesmo assim, na região de Campinas manteve-se o crescimento, embora a ritmo menor que o da capital.

Entre os anos 50 e 65, no plano da saúde, não ocorreu nenhuma alteração significativa. O modelo de saúde permanecia o mesmo existente na década de 30. A medicina privada e de caráter individual predominava com sua rede hospitalar geral ou especializada, juntamente com os antigos consultórios médicos conveniados aos IAPs. A região de Campinas, neste aspecto, em virtude da grande ampliação havida nos setores fabril e terciário, dos núcleos urbanos, bem como da própria população, passava por uma fase de expansão.

A saúde pública, de caráter coletivo, ainda limitava-se a cuidados com a vacinação, a puericultura, o controle de moléstias infecto-contagiosas e outros, destinadas sobretudo à população pobre (não assistida pelos IAPs). Tais serviços eram prestados em postos e centros de saúde, predominantemente estaduais, em várias localidades.

A prática da compra de serviços médicos e hospitalares pelos IAPs passa por grande aumento quantitativo, sendo inúmeros os estabelecimentos e médicos conveniados. Este sistema, graças à forma estabelecida de remuneração, ampliou em muito as despesas dos institutos. Tal prática ajudou, ainda, a fortalecer o papel dos hospitais na promoção da saúde.

Para 1965, o Centro de Pesquisa e Estudos Urbanísticos da Faculdade de Arquitetura e Urbanismo da Universidade de São Paulo registrou, para a subregião de Campinas, um número total de 17 hospitais, dispondo de um total de 2.264 leitos. Deste total, 923 leitos pertenciam a hospitais filantrópicos e 1.341 a hospitais com fins lucrativos. Portanto, nenhum dos leitos pertencia a entidade pública. O mesmo trabalho çita a razão de 3,8 leitos por mil habitantes, inferior à do Estado, que no mesmo ano era de 4,9 (São Paulo, 1967, p. 28).

Ainda no mesmo trabalho são apresentadas as razões leitos/1.000 habitantes, para o Estado, entre 1950 e 1965: 1950: 5,6; 1955: 5,4; 1958: 5,2; 1960: 5,3 e 1965: 4,9 (São Paulo, 1967, p. 16).

Estes dados apontam para a tendência de diminuição na oferta de número de leitos, em curso no Estado desde 1950. Outro problema verificado a partir da consideração dos mesmos indicadores é o fato de pouquíssimos dos hospitais serem mantidos pelas secretarias municipal ou estadual da saúde, apontando para um sério problema, ainda atual: a falta de leitos destinados às camadas de menor renda da população. Além desta questão, uma outra pode ser apontada: boa parte do total de leitos não pertence a hospitais gerais e sim a especializados (tuberculose, lepra e psiquiatria), estes sim de propriedade do Estado, o que reduz ainda mais a oferta de leitos para o conjunto da população.

No plano nacional, como foi visto no período, a única alteração no sistema de saúde foi a unificação dos IAPs numa única estrutura (1966/1967) denominada INPS. A criação de tal instituto deu-se com a crise do modelo previdenciário até então vigente, pois, em virtude da grande ampliação da massa trabalhadora e da demanda por assistência previdenciária e de saúde, bem como da multiplicidade 
de instituições e formas de remuneração pelos serviços, os IAPs passavam por aguda crise financeira. Por outro lado, o clima político então vigente, de centralismo autoritário, voltado para a constituição do mercado de trabalho e do consumo em nível nacional, bem como para cuidados com a reprodução da força de trabalho propiciavam tal organização da previdência.

Do lado da assistência propriamente dita, tanto social como de saúde, a unificação dos IAPs não significou grandes mudanças. Permaneceu o sistema de compra direta dos mais variados serviços por parte do INPS junto às empresas médico-hospitalares privadas (hospitais) e de profissionais liberais (médicos).

Nos anos 60, mesmo antes da criação do INPS, começava a se popularizar uma outra forma de contratação de serviços. Os contratos dos IAPs com as empresas médicas, de um lado, e com as empresas empregadoras (estabelecimentos diversos, tanto industriais, como comerciais e de serviços), de outro. Esta nova modalidade representava o início do empresariamento da medicina, através das empresas de "medicina de grupo" Tal modalidade passará por franco desenvolvimento já nos anos 70 , graças à implantação de grandes indústrias, especialmente no Estado de São Paulo, pois empregavam uma grande massa trabalhadora.

Este conjunto de novas modalidades surgiu e floresceu como forma da camada média da população urbana de fazer frente à precariedade dos serviços prestados pelo INPS, bem como aos crescentes custos dos cuidados privados com a saúde. Por outro lado, tais empresas também auxiliarão a rede de hospitais privados, pois muitos deles puderam descredenciar-se do INPS, em virtude da baixa remuneração pelos serviços para ele prestados.

$\mathrm{Na}$ cidade de Campinas tal empresariamento virá a ocorrer sobretudo após o início da década de 70, como será visto a seguir.

No plano econômico, a região de Campinas passaria a ser diretamente beneficiada pelo governo federal ao longo da década de 70 , por medidas que colaborariam para a ampliação do poderio econômico regional, bem como para sua consolidação como rede urbana complexa e una. Dentre tais medidas estavam a implantação da refinaria do planalto, na cidade vizinha de Paulínia, os investimentos do pró-álcool e a criação do pólo de microeletrônica. Antes porém, de tais investimentos tornarem-se realidade, praticamente toda a região já vivia a industrialização a pleno vapor, tanto que a população de diversos municípios passou a crescer assustadoramente.

Ao final da década, já está consolidado o desenho regional, bem como o forte inter-relacionamento entre as diversas cidades dela componentes. Iniciaram-se, então, novos e pesados investimentos estaduais no sistema rodoviário pela duplicação, pavimentação ou implantação de novas vias que iriam unir as diversas localidades num todo, hoje uno e indivisível, cada uma delas com funçōes (especializações) produtivas específicas, todavia complementares.

O grande crescimento populacional do período, por toda a região, evidenciou a intensidade da industrialização local. Durante este período, boa parte do referido crescimento deu-se pela chegada de grande quantidade de imigrantes, ampliando substancialmente as áreas urbanizadas dos diversos municípios, em especial naqueles onde a industrialização já havia se concretizado.

Para todas as cidades da região, tal desenvolvimento significou 0 início de problemas para sua população, que se tornaram mais complexas nos anos 80 . 
Retomando a questão das empresas médicas em Campinas. Em 1972, após muitas tentativas infrutíferas nos finais da década de 60 , em virtude da grande resistência das corporações médicas locais, implantou-se a Samcil, primeira das empresas do gênero na cidade. Precedendo sua implantação definitiva, a Samcil firmou convênio para atendimento dos funcionários da Pirelli e da Rhodia, iniciou a construção de um hospital (Samaritano) e adquiriu a Clínica Santo Antônio, recentemente remodelada e ampliada, com a denominação atual de Hospital Albert Sabin.

Nesta ocasião, a Unimed, que havia sido criada em 1970, disputava com a Samcil o convênio com a indústria Bosch, então uma das maiores empregadoras da região. A Unimed conseguiu o convênio e desde então transformou-se na maior das empresas prestadoras deste tipo de serviço na região. Atualmente a Unimed atende cerca de 370.000 beneficiários, distribuídos por 770 empresas, números estes superados apenas pelos obtidos no setor público.

Registrem-se ainda, no período, a construção de dois novos hospitais em Campinas, também privados, o mais antigo deles, o Centro Médico de Campinas hoje com 80 leitos, erigido em 1971 pela Fundação Robert Bosch do Brasil e o Centro Infantil Dr. Boldrini, hospital especializado em tratamento de câncer, construído nos anos 80 , também com o apoio financeiro da mesma fundação.

No início da década de 70 a rede regional de equipamentos de saúde da subregião de Campinas, no contexto da grande região administrativa do mesmo nome, segundo a Secretaria de Economia e Planejamento, era organizada da seguinte forma:

A rede básica era composta pelos centros de saúde estaduais, em número de 25 , distribuídos em 03 unidades do tipo I; 03 do tipo II; 02 do tipo III; 10 do tipo IV; 05 do tipo $V$ e 02 do tipo VI (São Paulo, 1973, p. O. 8.2/34). A classificação mencionada refere-se à relação, porte/complexidade de serviços, entre centro de saúde e população do município. Assim, o tipo I corresponde a localidades grandes e VI a pequenas localidades. Somados a estes centros de saúde, encontram-se alguns postos municipais, como os existentes em Campinas e os quatro Postos de Assistência Médica (PAM) do INPS, criados como postos de atendimento dos IAPs em Campinas, antes de sua unificação.

Acerca da rede hospitalar, observa-se, na mesma fonte (São Paulo, 1973, p. 8.2/ 42-8.2/43), que dos municípios estudados, somente alguns dispunham de hospital geral: Americana, Campinas, Cosmópolis, Indaiatuba, Pedreira, Valinhos, Vinhedo. Neste período, a proporção leitos/1.000 habitantes para a sub-região de Campinas era de 3,8 , indicando a continuidade no movimento descendente registrado des de 1950 .

Em virtude do acentuado crescimento populacional verificado em todas as cidades da região, ao longo de toda a década e do conseqüente agravamento da qualidade da vida urbana, teve início um movimento ainda incipiente por todo o Estado de reformas no setor saúde a partir de premissas sóciopolíticas indicativas da responsabilidade do Estado em relação às populações. Neste intuito, o Ministério da Saúde em ação conjunta com outros ministérios criou o sistema nacional de saúde, como meio de reorganizar a prestação de serviços públicos no setor. Os estados, por sua vez, sobretudo São Paulo, esforçaram-se para ampliar sua rede básica e hospitalar, assim como as prefeituras passaram a ser pressionadas para que tomassem a mesma atitude. Esta expansão dar-se-ia sem qualquer vínculo com a rede privada. 
A prefeitura de Campinas em 1969 dispunha de 01 pronto socorro, 01 posto central e 06 postos distritais de saúde. Já em 1973, o Pronto Socorro Municipal é transformado em Hospital Municipal Mário Gatti, constituindo-se no primeiro hospital público da região (Feliciello, 1985, p. 229). Lembre-se que o sistema regional era composto exclusivamente por estabelecimentos hospitalares privados lucrativos ou filantrópicos.

Entre os anos 1977 e 1978 são implantados 16 postos de saúde nos bairros periféricos, além dos 08 já existentes (04 estaduais e 04 municipais), e criados 02 hospitais universitários (PUCCAMP e UNICAMP).

Nas outras localidades da região que não contavam com hospitais, a maioria delas dispunha, para casos que requeriam de cuidados hospitalares, de prontosocorros municipais, como era o caso de Paulínia, Monte-Mór e Nova Odessa.

Com este conjunto de atividades, as prefeituras em geral iniciariam um trabalho em saúde que se expandiria nos anos seguintes, acompanhando as tendências e alteraçōes por que passariam as iniciativas por todo o país.

Na década de 80 , a região de Campinas consolidou definitivamente sua antiga posição de segunda região mais industrializada do Estado. Neste período, a economia regional passou por sucessivas ampliaçōes em seu parque fabril. Bem assim, Campinas, que além de suas funções no processo produtivo industrial, também acumula o posto de maior centro prestador de serviços, mantém-se como o maior município da regiāo, tornando-se, concomitantemente, o segundo do Estado. Estas características, como foi mostrado, foram historicamente determinadas.

Também neste período todas as cidades da região passaram a ter maioria absoluta de população urbana em relação à rural e algumas delas com crescimento superior ao de Campinas, como Sumaré, por exemplo.

\section{Considerações Finais}

Tomando-se por base os fatos expostos pode-se dizer que o papel de Campinas como capital regional remonta às suas origens, caracterizando-se como tal durante o ciclo do açúcar durante a segunda metade do século 19. Pode-se afirmar também, que no período cafeeiro esboçou-se o desenho da região de Campinas, com a paulatina ampliação do processo de polarização exercido por esta cidade, já que boa parte dos municípios criados no período, dela dependiam em maior ou menor grau, seja para consumo de serviços, seja como local de residência dos "barōes" do café.

No presente século, com os diversos momentos de industrialização, viu-se 0 aprofundamento deste papel, além, é claro, da profunda alteração da estrutura urbana, com base na redefinição dos papéis de cada um dos núcleos urbanos pertencentes à região. Ainda no século atual, como no anterior, novo conjunto de cidades foi criado com o desmembramento de antigos patrimônios de fazendas de café.

Em síntese, a dinâmica regional é um fato que foi historicamente definido e em outro nível de análise observou-se que se processou primeiramente a ocupação efetiva do Estado de São Paulo e posteriormente dos estados limítrofes (norte do Paraná, Mato Grosso do Sul, Triângulo e sul de Minas), as regiōes de povoamento e economia consolidadas (mais antigas) beneficiaram-se de tal 
processo, ampliando e aprofundando sua funções, sejam primárias, secundárias ou terciárias. Deste modo, a região de Campinas, como uma das mais antigas e das mais dinâmicas foi especialmente beneficiada por tais processos.

$\mathrm{Na}$ exata medida que Campinas foi ganhando importância no cenário estadual suas características urbanas transformaram-se também. Estruturou-se uma complexa gama de serviços e de infra-estrutura destinada a atender as demandas local e regional. Neste sentido, o sistema regional de saúde, assim como os demais sistemas, além das intervençōes urbanísticas nela realizadas, representaram, em última análise, a resposta da sociedade local aos processos de ordem macro, sejam econômicos, sejam sociais, que a transformaram cidade e região.

\section{Bibliografia}

BADARÓ. Ricardo de Souza Campos. O plano de melhoramentos urbanos de Campinas (19341962). São Carlos, 1986. Dissertação (Mestrado) - Escola de Engenharia de São Carlos, Universidade de São Paulo.

CAMPINAS. Prefeitura Municipal. Secretaria Municipal de Planejamento. Campinas: subsídios para a elaboração do Plano Diretor. Campinas: Secretaria Municipal de Planejamento, Prefeitura Municipal, 1991.

CANESQUI, Ana Maria, QUEIRÓZ, Marcos de S. Campinas: população, situação de saúde e organizaçāo do cuidado médico. Campinas: Núcleo de Estudos de Políticas Públicas, Universidade Estadual de Campinas.

CANO, Wilson. Desequilibrios regionais e concentração industrial do Brasil: 1930-1970. São Paulo: Global; Campinas: Editora da Universidade Estadual de Campinas, 1985.

. Raizes da concentração industrialem Sāo Paulo. 2. ed. SāoPaulo:T. A. Queiróz، 1983.

FELICIELLO, Domenico. Atenção primária e política de saúde. Campinas: PucCamp, 1985. (mimeo)

INSTITUTOBRASILEIRODE GEOGRAFIA E ESTATÍ́STICA. Enciclopédia dos municípios brasileiros. Rio de Janeiro: IBGE, 1957. v. XXVIII, v. XXIX, v. XXX.

L'ABBATE, Solange. O direito à saúde: da reivindicaçāo à realização. Projetos de política de saúde em Campinas. São Paulo, 1990. Tese (Doutorado) - Faculdade de Filosofia, Letras e Ciências Humanas, Universidade de São Paulo.

MARIANO, Júlio. Grandes estabelecimentos hospitalares de Campinas, ligados a instituiçōes diversas. In: Monografia histórica do município de Campinas. Rio de Janeiro: IBGE, 1952.

MASCARENHAS, Rodolfo dos S. Contribuição para o estudo da administração sanitária estadualem São Paulo. São Paulo, 1949. Tese (Livre-Docência)-Faculdade de Saúde Pública, Universidade de São Paulo.

MATOS, Odilon Nogueira de. Café e ferrovias:aevolução ferroviária de São Pauloeo desenvolvimento da cultura canavieira. 4. ed. Campinas: Pontes, 1990

MONBEIG, Pierre. Pioneiros e fazendeiros de São Paulo. Sāo Paulo: Hucitec e Polis, 1984.

OLIVEIRA, Jandira L. de. Contribuição para a história da saúde pública paulista: o projeto de revitalização do Museu de Saúde Pública Emílio Ribas. Sāo Paulo, 1986. Dissertação (Mestrado) - Pontifícia Universidade Católica de São Paulo.

PAULA, Carlos F. de. Assistência pública. In: Monografia histórica do município de Campinas. Rio de Janeiro: IBGE, 1952.

PEREIRA, Wlademir. Campinas na atualidade. In: Monografia histórica do município de Campinas. Rio de Janeiro: IBGE, 1952

PETRONE, Maria Thereza Schorer. A lavoura canavieira em São Paulo: expansão e declínio (17651851). São Paulo: Difusão Européia do Livro, 1968. 
PUPO, Celso Maria de Mello. Campinas, seu berçoe juventude. Campinas: Academia Campinense de Letras, 1969.

SÃO PAULO. Secretaria de Economia e Planejamento, Coordenadoria de Ação Regional. $5^{a}$ região administrativa: diagnóstico. São Paulo: Secretaria de Economia e Planejamento, Coordenadoria de Ação Regional, 1973.

Padrōes funcionais e espaciais da rede urbana do estado de São Paulo. São Paulo: Secretaria de Economia e Planejamento, Coordenadoria de Ação Regional, 1975.

Problemas emergentes do estado de São Paulo: subsídios à elaboração de uma estratégia. São Paulo: Secretaria de Economia e Planejamento, Coordenadoria de Ação Regional, 1976.

SÃO PAULO. Universidade de São Paulo, Faculdade de Arquitetura e Urbanismo, Centro de Pesquisa e Estudos Urbanísticos. Regionalização do estado de São Paulo: saúde. São Paulo:USP, FAU, CPEU, 1967.

SEMEGHINI, Ulysses Cidade. Campinas (1860 a 1980): agricultura, industrializaçāo e urbanização. Campinas, 1988. Dissertação (Mestrado) - Instituto de Economia, Universidade Estadual de Campinas.

SILVA, Kleber Pinto. Urbanização e sistema de saúde na regiāo de Campinas/SP. São Carlos, 1993. Dissertação (Mestrado) - Escola de Engenharia de São Carlos, Universidade de São Paulo

TARTAGLIA, JoséC., OLIVEIRA, Osvaldo L. de. Agricultura e interiorização do desenvolvimento em São Paulo. In: Modernização e desenvolvimento no interior de São Paulo. São Paulo: UNESP, 1988.

ZALUAR, Emílio Augusto. Peregrinaçāo pela província de São Paulo. São Paulo: Edusp, Belo Horizonte: Itatiaia, 1975 